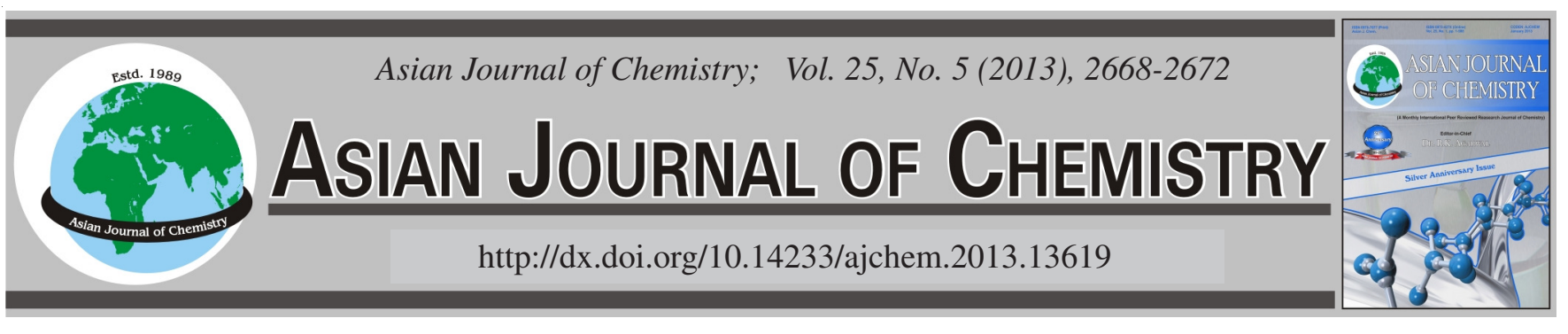

\title{
Synthesis, Characterization and Biological Evaluation of Some Novel Hydrazide Schiff's Bases and Their Metal Complexes
}

\author{
Mazhar Hussain, Zahid Shafiq*, Mian Hasnain Nawaz, Muhammad Aslam Shad, \\ Haq Nawaz, Muhammad Yaqub and Hafiz Badaruddin Ahmad
}

Department of Chemistry, Bahauddin Zakariya University, Multan, Pakistan

*Corresponding author: Fax: +92 61 9210138; Tel: +92 61 9210085; E-mail: z_shafiq@yahoo.com

(Received: 18 February 2012;

Accepted: 19 November 2012)

AJC-12425

\begin{abstract}
N'-(4-Hydroxy-3-methoxyphenyl)methylidene]formic hydrazide (L-1), N'-[-(4-hydroxy-3-methoxyphenyl)methylidene]-3'hydroxynaphthalene-2'-carbohydrazide (L-2) N'-[-(5-methylfuran-2-yl)methylidene]-3'-hydroxynaphthalene-2'-carbohydrazide (L-3), N'[-1"-(4-fluorophenyl)ethylidene]-3'-hydroxynaphthalene-2'-carbohydrazide (L-4) and N'-[(-1'-(4-chlorophenyl)ethylidene]formic hydrazide (L-5) were synthesized and tested for their antioxidant activity. All these newly synthesized Schiff's bases were treated with $\mathrm{Cu}$ (II), $\mathrm{Co}$ (II) and $\mathrm{Zn}(\mathrm{II})$ chlorides to form their respective complexes. Antioxidant activity of the synthesized ligands (L-1, L-2, L-3, L-4 and L-5), their corresponding metal(II) complexes, salts of the metal used in the complex formation and Trolox (as standard antioxidant) was measured in terms of their ability to scavenge the DPPH free radical. Ligand (L-4) was found to be the best antioxidant among all the ligands. As regards the activity of metal(II) complexes, Zn-L-4 exhibited the best antioxidant activity.
\end{abstract}

Key Words: Hydrazones, Hydrazides, Schiff's bases, Antioxidant activity.

\section{INTRODUCTION}

Oxidative stress is a well-known mechanism that is responsible for the development of vascular damage. Different pathogenic stimuli involved in cardiovascular diseases, such as activated macrophages, hyperglycaemia, oxidized lowdensity lipoprotein (LDL), exert their harmful effects, at least partially, through an increased local generation of reactive oxygen species. Reactive oxygen species (ROS) are normally produced throughout oxygen metabolism and play a major role in physiological and pathological cell redox signaling ${ }^{1}$. Besides the direct free radical attack of cellular components, oxidative stress induces a lipid peroxidation of cellular membranes resulting in the generation of reactive carbonyl compounds (RCC) that react rapidly with free amino groups and thiol residues on proteins thereby forming adducts involved in the carbonyl stress ${ }^{2,3}$. Both oxidative and carbonyl stress alter protein function and trigger the accumulation of modified proteins, which results in inflammation and apoptosis ${ }^{3,4}$. Antioxidants inhibit the generation of ROS and the subsequent formation of lipid peroxidation products, thereby preventing both oxidative and carbonyl stress. Most antioxidants prevent LDL oxidation in cell-dependent and cell-free systems, and delay the formation of atherosclerotic lesions in animal models for atherosclerosis such as apoE-/-mice ${ }^{5}$. The best compounds in term of antioxidant and cytoprotective effects was found to be the symmetrical compound bearing two hydrazine scaffolds while all other ones were much less potent.

Hydrazones have been found with wide applications in synthetic chemistry ${ }^{6}$, to be used as indicators. Hydrazones are now being used extensively in detection and quantitative determination of several metals, for the preparation of compounds having diverse structures, analytical chemistry for the identification and isolation of carbonyl compounds ${ }^{7,8}$. However, the most valuable property of hydrazones is, perhaps, their great physiological activity. The hydrazones have also been used for different purposes such as herbicides, insecticides, nematocides, redenticides and plant growth regulators ${ }^{9}$. The hydrazones are also important for their use as plasticizers and stabilizers for polymers ${ }^{10,11}$, polymerization initiators and antioxidants $^{12}$. A polyphenol antioxidant is a type of antioxidant containing a polyphenolic substructure. Numbering over 4,000 distinct species, these compounds have antioxidant activity in vitro but are unlikely to have antioxidant roles in vivo ${ }^{13}$. Rather, they may affect cell-to-cell signalling, receptor sensitivity, inflammatory enzyme activity or gene regulation ${ }^{14}$.

In order to get insight on the efficiency of the hydrazone functionality, we report here the synthesis of some hydrazones. Keeping in view the promising use of potentially metal-based antimicrobial, antioxidant and antiinflammatory properties, 
some metal-based $[(\mathrm{Cu}(\mathrm{II}), \mathrm{Co}(\mathrm{II})$ and $\mathrm{Zn}(\mathrm{II})]$ compounds incorporated with some novel formichydrazides and naphthalene-2-carbohydrazides (L-1-L-5) Schiff's bases are reported.

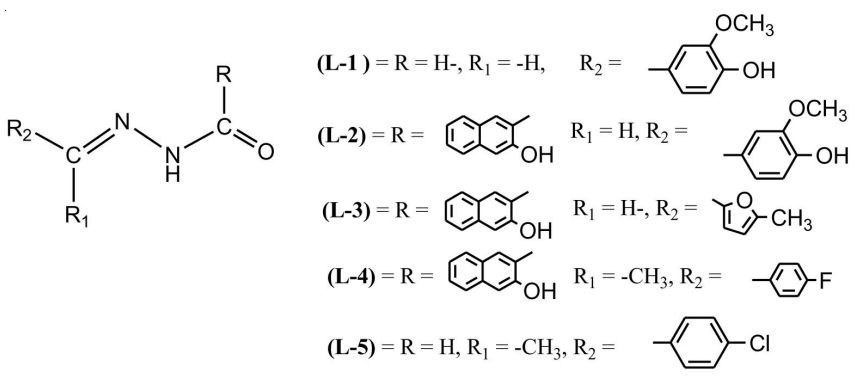

Fig. 1. Structure of ligands

\section{EXPERIMENTAL}

Solvents used were of analytical grade and all metals(II) were used as their chloride salts. IR spectra were recorded on 8400-FTIR Spectrophotometer using KBr disc method. NMR spectra were recorded on a Bruker-300 MHz NMR spectrophotometer. UV-Visible spectra were obtained in DMSO on IMRECO UV-VIS spectrophotometer, model U-2020. Conductance of the metal complexes was determined in DMSO on conductometer, Hitachi (Japan), model YSI-32. Melting points were recorded on a Gallenkamp melting point apparatus and are uncorrected. The complexes were analyzed for their metal contents by EDTA titrations ${ }^{15}$. Proton magnetic resonance spectra were recorded in $\mathrm{CDCl}_{3}$ and DMSO- $d_{6}$ on Bruker AM 300 and AM 400 spectrometers (Rheinstetten-Forchheim, Germany) operating at 300 and $400 \mathrm{MHz}$, respectively. Tetramethyl-silance was used as an internal standard.

\section{Preparation of Schiff's base}

Synthesis of $N^{\prime}$-[(E)-(4-hydroxy-3-methoxyphenyl) methylidene] formic hydrazide (L-1): To a hot stirred solution of formic acid hydrazide $(1 \mathrm{~g}, 0.017 \mathrm{~mol})$ in ethanol $(15 \mathrm{ml})$, vanillin $(2.53 \mathrm{~g}, 0.017 \mathrm{~mol})$ was added. The reaction mixture was heated under reflux for $1.5 \mathrm{~h}$. During reflux precipitates were formed. The reaction was monitored through TLC. After completion of reaction, the mixture was cooled at room temperature. The solid material was collected by suction filtration. The precipitates were washed with hot ethanol, filtered and dried. Yield $55 \%$, white powder; m.p. $170{ }^{\circ} \mathrm{C}$; IR $\left(\mathrm{KBr}, \mathrm{n}_{\max }, \mathrm{cm}^{-1}\right): 3320(\mathrm{OH}), 3055(\mathrm{NH}), 1680(>\mathrm{C}=\mathrm{O}), 1650$ $(>\mathrm{C}=\mathrm{N}), \mathrm{UV}$ (DMSO) $\lambda_{\max }(\mathrm{nm}) 218$; non-electrolyte; ${ }^{1} \mathrm{H}$ NMR (DMSO) $\delta: 6.82\left(\mathrm{~d}, J=8 \mathrm{~Hz}, 1 \mathrm{H}, \mathrm{C}_{5}-\mathrm{H}\right), 6.95\left(\mathrm{~m}, 2 \mathrm{H}, \mathrm{C}_{2,6}-\mathrm{H}\right)$, 7.24 (s, 1H, CHN), 3.32 (s, 1H, C $4-\mathrm{OH}), 3.87$ (s $3 \mathrm{H},-\mathrm{OCH}_{3}$ ), $7.73(\mathrm{~s}, 1 \mathrm{H}, \mathrm{NH}), 8.65(\mathrm{~s}, 1 \mathrm{H}, \mathrm{CHO}) \mathrm{ppm}$. EIMS $(\mathrm{m} / \mathrm{z})=194$ $\left(\mathrm{M}^{+}\right), 165,148,134,123,106$.

Synthesis of 3'-hydroxy-N'-[(Z)-(4-hydroxy-3methoxyphenyl)methylidene]naph thalene-2' -carbohydrazide (L-2): To a hot stirred solution of 3-hydroxy-2naphthoic hydrazide $(1.5 \mathrm{~g}, 0.0074 \mathrm{~mol})$ in a mixture of ethanol $(50 \mathrm{~mL})$ and 1,2-dioxane $(2 \mathrm{~mL})$, vanillin $(1.13 \mathrm{~g}$, $0.0074 \mathrm{~mol})$ was added. The reaction mixture was heated under reflux for $10 \mathrm{~h}$. The product was purified according to the previous procedure. Yield $95 \%$, yellow powder; m.p. 152 ${ }^{\circ} \mathrm{C}$; IR (KBr, $\left.\mathrm{n}_{\max }, \mathrm{cm}^{-1}\right): 3307,3307(-\mathrm{OH}), 3145(\mathrm{NH}), 1660$
$(>\mathrm{C}=\mathrm{O}), 1595(-\mathrm{HC}=\mathrm{N}-), 1520\left(-\mathrm{OCH}_{3}\right), \mathrm{UV}(\mathrm{DMSO}) \lambda_{\max }$ (nm) 227; non-electrolyte; ${ }^{1} \mathrm{H}$ NMR (DMSO) $\delta: 3.91$ ( s, 3H, $\left.-\mathrm{OCH}_{3}\right), 7.00\left(\mathrm{~d}, J=8 \mathrm{~Hz}, 1 \mathrm{H}, \mathrm{C}_{2}-\mathrm{H}\right), 6.83(\mathrm{~d}, J=8 \mathrm{~Hz}, 1 \mathrm{H}$, $\left.\mathrm{C}_{5}-\mathrm{H}\right), 7.26\left(\mathrm{~m}, 4 \mathrm{H}, \mathrm{C}_{6,1^{\prime}, 4^{\prime}, 7^{\prime}}-\mathrm{H}\right), 7.42\left(\mathrm{~m}, 1 \mathrm{H}, \mathrm{C}_{6^{\prime}}-\mathrm{H}\right), 7.61(\mathrm{~d}$, $\left.J=7.6 \mathrm{~Hz}, 2 \mathrm{H}, \mathrm{C}_{5^{\prime}, 8^{\prime}} \mathrm{H}\right), 7.75$ ( s, 1H, CHN), 8.14 ( s, 1H, $\left.\mathrm{C}_{3^{\prime}}-\mathrm{OH}\right), 8.39(\mathrm{~s}, 1 \mathrm{H}, \mathrm{NH}) \mathrm{ppm}$. EIMS $(\mathrm{m} / \mathrm{z})=336\left(\mathrm{M}^{+}\right), 171$, $165,143,117$.

Synthesis of 3'-hydroxy-N'-[(E)-(5-methylfuran-2-yl)methylidene]naphthalene-2'-carbohydrazide (L-3): To a hot stirred solution of 3-hydroxy-2-naphthoic hydrazide (1.5 g, $0.0074 \mathrm{~mol})$ in mixture of ethanol $(35 \mathrm{~mL})$ and 1,2-dioxane ( $2 \mathrm{~mL}), 5$-methyl furfural $(0.736 \mathrm{~mL}, 0.0074 \mathrm{~mol})$ was added. The reaction mixture was heated under reflux for $2 \mathrm{~h}$. The product was purified according to the previous procedure. Yield $87 \%$, yellow powder; m.p. $206^{\circ} \mathrm{C}$; IR $\left(\mathrm{KBr}, v_{\max }, \mathrm{cm}^{-1}\right): 3230$ (OH), $3055(\mathrm{NH}), 1647(>\mathrm{C}=\mathrm{O}), 1575(>\mathrm{C}=\mathrm{N}-)$, UV (DMSO) $\lambda_{\max }(\mathrm{nm}) 348$; non*electrolyte; ${ }^{1} \mathrm{H}$ NMR (DMSO) $\delta: 7.74$ (d, $\left.J=7.6 \mathrm{~Hz}, 1 \mathrm{H}, \mathrm{C}_{4}-\mathrm{H}\right), 7.67\left(\mathrm{~d}, J=8 \mathrm{~Hz}, 1 \mathrm{H}, \mathrm{C}_{3}-\mathrm{H}\right), 2.36$ (s, $\left.3 \mathrm{H}, \mathrm{CH}_{3}\right), 7.29\left(\mathrm{~m}, 3 \mathrm{H}, \mathrm{C}_{1^{\prime}, 4^{\prime}, 7^{-}}-\mathrm{H}\right), 7.47\left(\mathrm{~m}, 1 \mathrm{H}, \mathrm{C}_{6 ;}-\mathrm{H}\right), 7.61$ $\left(\mathrm{d}, J=7.6 \mathrm{~Hz}, 2 \mathrm{H}, \mathrm{C}_{5^{\prime}, 8^{\prime}}-\mathrm{H}\right), 8.22$ (s, 1H, $\left.\mathrm{C}_{3^{\prime}}-\mathrm{OH}\right), 8.39$ (s, $1 \mathrm{H}$, $\mathrm{NH}), 7.75(\mathrm{~s}, 1 \mathrm{H}, \mathrm{CHN}) \mathrm{ppm}$. EIMS $(\mathrm{m} / \mathrm{z})=294\left(\mathrm{M}^{+}\right), 171$, $123,143,115,79$.

Synthesis of N'-[(1Z)-1"'-(4-fluorophenyl)ethylidene]3'-hydroxy naphthalene-2'-carbohydrazide (L-4): To a hot stirred solution of 3-hydroxy-2-naphthoic hydrazide (1.5 g, $0.0074 \mathrm{~mol})$ in ethanol $(40 \mathrm{~mL}), 4$-fluroacetophenone $(0.9 \mathrm{~mL}$, $0.0074 \mathrm{~mol}$ ) was added. The reaction mixture was heated under reflux for $12 \mathrm{~h}$. The product was purified according to the previous procedure. Yield $87 \%$, cream coloured powder; m.p. $270^{\circ} \mathrm{C}$; IR (KBr, $\left.v_{\max }, \mathrm{cm}^{-1}\right): 3593(\mathrm{OH}), 3143$ (-NH-), 1639 (>C=O), 1623, (-C=N-), UV (DMSO) $\lambda_{\max }$ (nm) 336; non-electrolyte; ${ }^{1} \mathrm{H}$ NMR (DMSO) $\delta: 2.37\left(\mathrm{~s}, 3 \mathrm{H}, \mathrm{CH}_{3}\right), 7.29$ $\left(\mathrm{m}, 3 \mathrm{H}, \mathrm{C}_{1^{\prime}, 4^{\prime}, 7^{\prime}}-\mathrm{H}\right), 7.47\left(\mathrm{~m}, 1 \mathrm{H}, \mathrm{C}_{6} ;-\mathrm{H}\right), 7.61(\mathrm{~d}, J=7.6 \mathrm{~Hz}$, $\left.2 \mathrm{H}, \mathrm{C}_{5^{\prime}, 8^{\prime}} \mathrm{H}\right), 8.23\left(\mathrm{~s}, 1 \mathrm{H}, \mathrm{C}_{3^{\prime}}-\mathrm{OH}\right), 8.43(\mathrm{~s}, 1 \mathrm{H}, \mathrm{NH}), 8.71(\mathrm{~d}$, $\left.J=8.7 \mathrm{~Hz}, 2 \mathrm{H}, \mathrm{C}_{3,5}-\mathrm{H}\right), 7.90\left(\mathrm{~d}, J=8.7 \mathrm{~Hz}, 2 \mathrm{H}, \mathrm{C}_{2,6}-\mathrm{H}\right) \mathrm{ppm}$. EIMS $(\mathrm{m} / \mathrm{z})=322\left(\mathrm{M}^{+}\right), 171,151,115,83$.

Synthesis of N'-[(1E)-1'-(4-chlorophenyl)ethylidene]formic hydrazide (L-5): To a hot stirred solution of formic hydrazide $(1 \mathrm{~g}, 0.017 \mathrm{~mol})$ in ethanol $(15 \mathrm{~mL})$, 4-chloroacetophenone $(1.37 \mathrm{~g}, 0.01 \mathrm{~mol})$ was added. The reaction mixture was heated under reflux for $5 \mathrm{~h}$. The product was purified according to the previous procedure. Yield $88 \%$, white powder; m.p. $195^{\circ} \mathrm{C}$; IR (KBr, $\left.v_{\max }, \mathrm{cm}^{-1}\right)$ : 3201 (-NH-), $1695(>\mathrm{C}=\mathrm{O})$, 1615 (>C=N-), 700 (>C-Cl), UV (DMSO) $\lambda_{\max }(\mathrm{nm}) 272$; nonelectrolyte; ${ }^{1} \mathrm{H}$ NMR( DMSO) $\delta: 2.22\left(\mathrm{~s}, 3 \mathrm{H}, \mathrm{CH}_{3}\right), 7.46(\mathrm{~d}$, $\left.J=8.7 \mathrm{~Hz}, 2 \mathrm{H}, \mathrm{C}_{3,5}-\mathrm{H}\right), 7.77\left(\mathrm{~d}, J=8.7 \mathrm{~Hz}, 2 \mathrm{H}, \mathrm{C}_{2,6}-\mathrm{H}\right), 8.75$ (s, 1H, NH), $11.12(\mathrm{~s}, 1 \mathrm{H}, \mathrm{CHO}) \mathrm{ppm}$. EIMS $(\mathrm{m} / \mathrm{z})=196$ $\left(\mathrm{M}^{+}\right), 181,167,153,137,102$.

\section{Synthesis of metal(II) complexes}

Synthesis of copper(II) complex (Cu-L-1): Copper(II) chloride dihydrate $(1.3 \mathrm{mmol} 0.218 \mathrm{~g})$ was added to a magnetically stirred solution of L-1 (2.6 mmol, $0.5 \mathrm{~g})$ in 1,4dioxane $(20 \mathrm{~mL})$. The mixture was refluxed for $1 \mathrm{~h}$. Precipitates were formed during reflux. The product was filtered, washed with ethanol and dried. The dried precipitates were kept in desicator. All other $\mathrm{Cu}$ (II), $\mathrm{Co}$ (II) and $\mathrm{Zn}$ (II) complexes of ligands (L-1 to L-5) were synthesized according to the same method. 


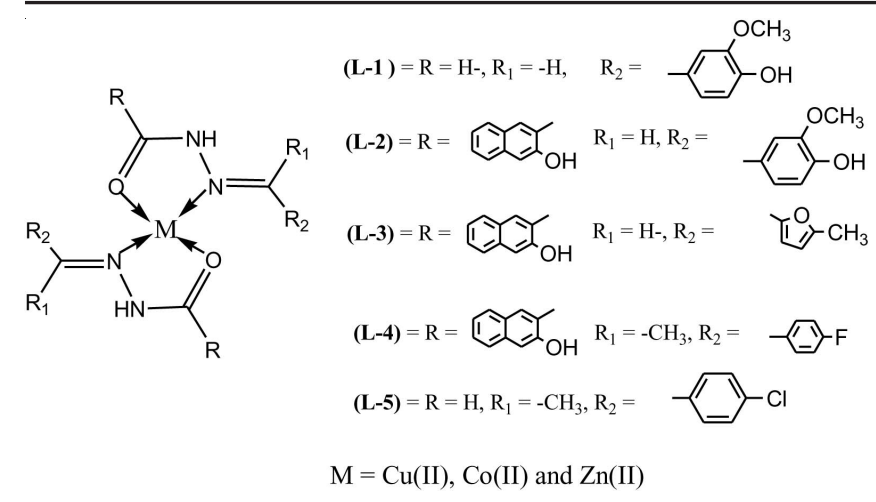

Fig. 2. Structures of metal(II) complexes

\section{Antioxidant analysis}

Method for antioxidant activity: The antioxidant activity of the ligands (L-1, L-2, L-3, L-4 and L-5) and their metal(II) complexes, salts of corresponding metals and Trolox (as standard antioxidant) was determined by 1,1-diphenyl-2picrylhydrazyl (DPPH) radical scavenging method of BrandWilliams et al. ${ }^{16}$. The methanolic solutions $(0.1 \mathrm{~mL})$ of the ligands, metal complexes, salts and Trolox were mixed with $40 \mu \mathrm{M}$ methanolic DPPH ${ }^{\bullet}$ solution $(2.9 \mathrm{~mL})$ and absorbance was recorded after $0.5 \mathrm{~h}$ at $517 \mathrm{~nm}$ using a UV-Visible spectrophotometer. The antioxidant ability was calculated in terms of $\mathrm{DPPH}^{\bullet}$ inhibition by a linear regression equation obtained from a calibration curve $\left(\mathrm{R}^{2}=0.9902\right)$ of $\mathrm{DPPH}^{\circ}$ :

$$
\mathrm{Abs}_{517 \mathrm{~nm}}=0.2533 \times\left[\mathrm{DPPH}^{\circ}\right](\mu \mathrm{g})
$$

The $\% \mathrm{DPPH}^{\bullet}$ remaining was calculated as:

$$
\left[\mathrm{DPPH}^{*}\right]_{\mathrm{R}}(\%)=100 \times\left[\mathrm{DPPH}^{*}\right]_{\mathrm{T}} \div\left[\mathrm{DPPH}^{*}\right]_{\mathrm{T}=0}
$$

where, $\left[\mathrm{DPPH}^{\circ}\right]_{\mathrm{T}}$ is the remaining concentration of $\mathrm{DPPH}^{\circ}$ at $0.5 \mathrm{~h}$ time while $\left[\mathrm{DPPH}^{\circ}\right]_{\mathrm{T}=0}$ is the initial concentration of $\mathrm{DPPH}^{\circ}$.

A kinetic study was also conducted to evaluate the free radical scavenging properties of the ligands, their complexes with metals(II), salts of corresponding metals and Trolox at varying time intervals. The percentage of remaining $\mathrm{DPPH}^{\bullet}$ at every $5 \mathrm{~min}$ interval up to $30 \mathrm{~min}$ was plotted against time to obtain the initial time at which the samples inhibit the maximum concentration of $\mathrm{DPPH}^{\circ}$.

\section{RESULTS AND DISCUSSION}

Chemistry of Schiff's base ligands (L-1-L-5) and their metal complexes: Ethanolic solutions of formic acid hydrazide with vanillin and 4-chloroacetophenone were refluxed to synthesize Schiff bases (L-1) and (L-5) respectively. Similarly to get Schiff's bases (L-2), (L-3) and (L-4), 3-hydoxy-2naphthoic acid hydrazide separately was refluxed with vanillin, 5-methyl-2-furfural and 4-fluroacetophenone. The structures of these Schiff's bases formed were elucidated by IR, NMR, mass spectrometry and micro analytical data. These Schiff's bases were further used for the complexation reaction with $\mathrm{Cu}$ (II), $\mathrm{Co}$ (II) and Zn(II) metal ions. All of the newly synthesized metal complexes were found to be stable in air and moisture. They were prepared by the stoichiometric reaction with the corresponding metal(II) chlorides and the Schiff's bases (L-1 to L-5) in the molar ratios (M:L) 1:2. The complexes are amorphous solids, which are decomposed above $100^{\circ} \mathrm{C}$. These are insoluble in common organic solvents (chloroform, acetone, ethanol and methanol), but soluble in DMSO and DMF. All the complexes exhibited high values of molar conductance (31-116 $\left.\Omega^{-1} \mathrm{~cm}^{2} \mathrm{~mol}^{-1}\right)$ determined in DMSO which show their ionic and electrolyte nature.

In the IR spectra of ligands the disappearance of absorption band at 1735 and $3420 \mathrm{~cm}^{-1}$ due to carbonyl $\mathrm{v}(\mathrm{C}=\mathrm{O})$ and $v\left(\mathrm{NH}_{2}\right)$ stretching vibrations and a new band appeared at ca. $1607 \mathrm{~cm}^{-1}$ assigned ${ }^{17}$ to the azomethine $\mathrm{v}(\mathrm{HC}=\mathrm{N})$ linkage indicate that amino and aldehyde moieties of the starting reagents have been converted into their corresponding Schiff's bases. The $v(\mathrm{NH})$-amide, $v(\mathrm{C}=\mathrm{O})$-amide and $v(\mathrm{NNH})$-imino stretching frequencies were present at 3440, 1679 and 1607 $\mathrm{cm}^{-1}$, respectively. A comparison ${ }^{18}$ of the IR spectra of the Schiff's bases to their metal(II) complexes (Table-1) indicated that the Schiff's bases are coordinated to the metal atom mainly in two ways, thus the ligands are acting in a bidentate manner. The band absorption at $1607 \mathrm{~cm}^{-1}$ corresponding to azomethine group was shifted to lower frequencies by ca. $20 \mathrm{~cm}^{-1}$, indicating participation of the azomethine nitrogen is coordinated ${ }^{19}$. A new medium strong band appearing at $540-533 \mathrm{~cm}^{-1}$ is assigned to $v(\mathrm{M}-\mathrm{O})^{20}$. This demonstrated that oxygen of the $\mathrm{C}=\mathrm{O}$-amide has formed a coordinate bond with the metal ions in an enolic form. A weak band at $420,440 \mathrm{~cm}^{-1}$ is assigned to $v(\mathrm{M}-\mathrm{N})$. This further confirms that the nitrogen of the $\mathrm{HN}$-imino group bonds to the metal atom. All of the data establishes that a conjugate chelate ring formed by ligand enolization exists in the complexes.

NMR spectrum of the ligand was determined in DMSO. ${ }^{1} \mathrm{H}$ NMR spectral data are reported along with possible

TABLE-1

\begin{tabular}{|c|c|c|c|c|}
\hline No. & Metal complexes / m.f. & m.p. / d.p. $\left({ }^{\circ} \mathrm{C}\right)$ & $\lambda_{\max }(\mathrm{nm})$ & $\operatorname{IR}\left(\mathrm{cm}^{-1}\right)$ \\
\hline 1 & {$\left[\mathrm{Cu}(\mathrm{L}-1)_{2} \mathrm{Cl}_{2}\right] / \mathrm{C}_{16} \mathrm{H}_{18} \mathrm{~N}_{4} \mathrm{O}_{6} \mathrm{CuCl}_{2}[522]$} & 170 & 381 & $1650(\mathrm{CO}), 1585(\mathrm{C}=\mathrm{N}), 510(\mathrm{M}-\mathrm{O}), 435(\mathrm{M}-\mathrm{N})$ \\
\hline 2 & {$\left[\mathrm{Co}(\mathrm{L}-1)_{2} \mathrm{Cl}_{2}\right] / \mathrm{C}_{16} \mathrm{H}_{18} \mathrm{~N}_{4} \mathrm{O}_{6} \mathrm{CoCl}_{2}[518]$} & 300 & 415 & $1630(\mathrm{CO}), 1610(\mathrm{C}=\mathrm{N}), 545(\mathrm{M}-\mathrm{O}), 440(\mathrm{M}-\mathrm{N})$ \\
\hline 3 & {$\left[\mathrm{Zn}(\mathrm{L}-1)_{2} \mathrm{Cl}_{2}\right] / \mathrm{C}_{16} \mathrm{H}_{18} \mathrm{~N}_{4} \mathrm{O}_{6} \mathrm{ZnCl}_{2}[524]$} & 115 & 399 & $1650(\mathrm{CO}), 1600(\mathrm{C}=\mathrm{N}), 532(\mathrm{M}-\mathrm{O}), 430(\mathrm{M}-\mathrm{N})$ \\
\hline 4 & {$\left[\mathrm{Cu}(\mathrm{L}-2)_{2} \mathrm{Cl}_{2}\right] / \mathrm{C}_{38} \mathrm{H}_{26} \mathrm{~N}_{4} \mathrm{O}_{8} \mathrm{CuCl}_{2}[806]$} & 155 & 364 & $1637(\mathrm{CO}), 1593(\mathrm{C}=\mathrm{N}), 535(\mathrm{M}-\mathrm{O}), 415(\mathrm{M}-\mathrm{N})$ \\
\hline 5 & {$\left[\mathrm{Co}(\mathrm{L}-2)_{2} \mathrm{Cl}_{2}\right] / \mathrm{C}_{38} \mathrm{H}_{26} \mathrm{~N}_{4} \mathrm{O}_{8} \mathrm{CoCl}_{2}[802]$} & 220 & 331 & $1625(\mathrm{CO}), 1595(\mathrm{C}=\mathrm{N}), 525(\mathrm{M}-\mathrm{O}), 455(\mathrm{M}-\mathrm{N})$ \\
\hline 6 & {$\left[\mathrm{Zn}(\mathrm{L}-2)_{2} \mathrm{Cl}_{2}\right] / \mathrm{C}_{38} \mathrm{H}_{26} \mathrm{~N}_{4} \mathrm{O}_{8} \mathrm{ZnCl}_{2}[808]$} & 280 & 438 & $1632(\mathrm{CO}), 1601(\mathrm{C}=\mathrm{N}), 533(\mathrm{M}-\mathrm{O}), 435(\mathrm{M}-\mathrm{N})$ \\
\hline 7 & {$\left[\mathrm{Cu}(\mathrm{L}-3)_{2} \mathrm{Cl}_{2}\right] / \mathrm{C}_{34} \mathrm{H}_{28} \mathrm{~N}_{4} \mathrm{O}_{6} \mathrm{CuCl}_{2}[722]$} & 200 & 445 & $1635(\mathrm{CO}), 1602(\mathrm{C}=\mathrm{N}), 530(\mathrm{M}-\mathrm{O}), 425(\mathrm{M}-\mathrm{N})$ \\
\hline 8 & {$\left[\mathrm{Co}(\mathrm{L}-3)_{2} \mathrm{Cl}_{2}\right] / \mathrm{C}_{34} \mathrm{H}_{28} \mathrm{~N}_{4} \mathrm{O}_{6} \mathrm{CoCl}_{2}[718]$} & 230 & 437 & $1635(\mathrm{CO}), 1560(\mathrm{C}=\mathrm{N}), 535(\mathrm{M}-\mathrm{O}), 455(\mathrm{M}-\mathrm{N})$ \\
\hline 9 & {$\left[\mathrm{Zn}(\mathrm{L}-3)_{2} \mathrm{Cl}_{2}\right] / \mathrm{C}_{34} \mathrm{H}_{28} \mathrm{~N}_{4} \mathrm{O}_{6} \mathrm{ZnCl}_{2}[724]$} & 125 & 468 & $1632(\mathrm{CO}), 1595(\mathrm{C}=\mathrm{N}), 505(\mathrm{M}-\mathrm{O}), 435(\mathrm{M}-\mathrm{N})$ \\
\hline 10 & {$\left[\mathrm{Cu}(\mathrm{L}-4)_{2} \mathrm{Cl}_{2}\right] / \mathrm{C}_{38} \mathrm{H}_{30} \mathrm{~N}_{4} \mathrm{O}_{4} \mathrm{CuCl}_{2}[778]$} & 300 & 409 & $1638(\mathrm{CO}), 1550(\mathrm{C}=\mathrm{N}), 520(\mathrm{M}-\mathrm{O}), 442(\mathrm{M}-\mathrm{N})$ \\
\hline 11 & {$\left[\mathrm{Co}(\mathrm{L}-4)_{2} \mathrm{Cl}_{2}\right] / \mathrm{C}_{38} \mathrm{H}_{30} \mathrm{~N}_{4} \mathrm{O}_{4} \mathrm{CoCl}_{2}[774]$} & 242 & 458 & $1639(\mathrm{CO}), 1600(\mathrm{C}=\mathrm{N}), 525(\mathrm{M}-\mathrm{O}), 445(\mathrm{M}-\mathrm{N})$ \\
\hline 12 & {$\left[\mathrm{Zn}(\mathrm{L}-4)_{2} \mathrm{Cl}_{2}\right] / \mathrm{C}_{38} \mathrm{H}_{30} \mathrm{~N}_{4} \mathrm{O}_{4} \mathrm{ZnCl}_{2}[780]$} & 220 & 474 & $1630(\mathrm{CO}), 1610(\mathrm{C}=\mathrm{N}), 520(\mathrm{M}-\mathrm{O}), 433(\mathrm{M}-\mathrm{N})$ \\
\hline 13 & {$\left[\mathrm{Cu}(\mathrm{L}-5)_{2} \mathrm{Cl}_{2}\right] / \mathrm{C}_{18} \mathrm{H}_{18} \mathrm{~N}_{4} \mathrm{O}_{2} \mathrm{Cl}_{2} \mathrm{CuCl}_{2}[526]$} & 170 & 431 & $1670(\mathrm{CO}), 1510(\mathrm{C}=\mathrm{N}), 560(\mathrm{M}-\mathrm{O}), 455(\mathrm{M}-\mathrm{N})$ \\
\hline
\end{tabular}

MELTING/DECOMPOSITION POINTS AND UV-VISIBLE, IR SPECTRAL DATA OF THE SYNTHESIZED COMPLEXES 
assignments. All the protons were found to be in their expected regions $^{21,22}$.

Mass spectra were determined by the instrument JEOL MS Route and MAT 312 that gives us different fragments of the Schiff bases. Molecular ion peaks were appeared at same value of the molecular weight of Schiff's bases.

The conclusions drawn from these studies further support to the mode of bonding discussed in their IR spectra. It was also observed that DMSO did not have any coordinating effect on the spectra of ligands or their metal complexes.

Antioxidant activity: The antioxidant activity of the synthesized ligands (L-1, L-2, L-3, L-4 and L-5), their corresponding metal(II) complexes, salts of the metal used in complex formation and Trolox (as standard antioxidant) was measured in terms of their ability to scavenge the DPPH free radical. Among the ligands, L-4 was found to be a good antioxidant followed by L-2 and L-1 while L-5 showed comparatively lowest antioxidant activity. Among the metal(II) complexes of these ligands, the salts of $\mathrm{Zn}(\mathrm{II})$ with each ligand showed good response regarding the inhibition of $\mathrm{DPPH}^{\circ}$. Zn-L-4 was found to be the best antioxidant followed by Co-L-2, Co-L-4 Zn-L-2 and Zn-L-5 which also showed more than $50 \%$ inhibition of $\mathrm{DPPH}^{\circ}$. The $\mathrm{Cu}$ (II) complexes of each of the ligands were found to be poor antioxidants as compared to the respective ligand. The salts of all of the three metals also showed low antioxidant activities as compared to the ligands and their corresponding complexes. However, the antioxidant activity of all of the ligands, metal complexes and the salts were found to be low as compared to Trolox (Fig. 3).

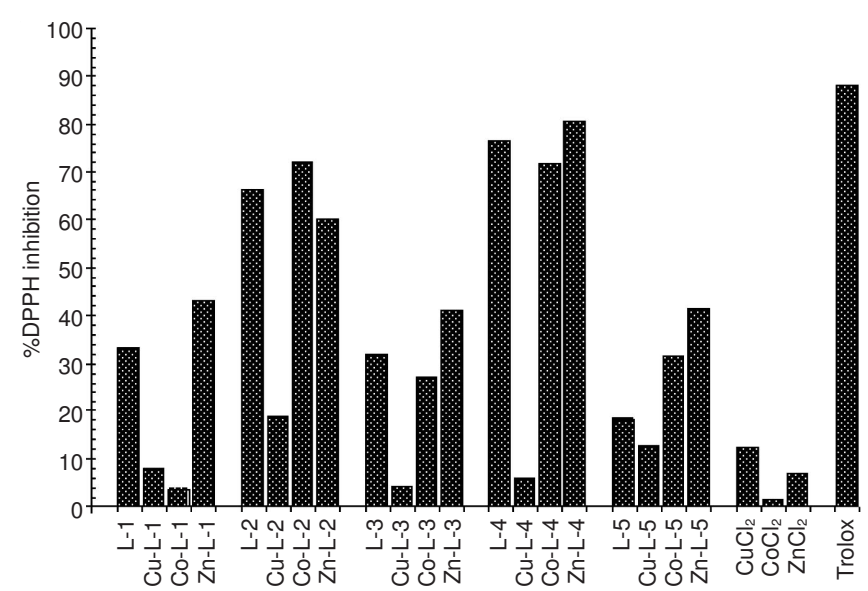

Fig. 3. Comparative antioxidant activity (\% inhibition of $\mathrm{DPPH}^{\bullet}$ ) of synthesized ligands, their metal complexes, salts of respective metals and a standard antioxidant (Trolox)

The kinetic behavior of $\mathrm{DPPH}^{\bullet}$ inhibition by the ligands, their metal complexes and salts of metals showed that these ligands and their complexes with cobalt(II) and $\mathrm{Zn}$ (II) cause a sharp decrease in $\mathrm{DPPH}^{\bullet}$ concentration within first $5 \mathrm{~min}$ (Fig. 4A,C). After 5 min a slow decrease in the remaining $\mathrm{DPPH}^{\circ}$ concentration was observed to be continued for $0.5 \mathrm{~h}$ in each case. The salts of each metal and the complexes of the ligands with $\mathrm{Cu}(\mathrm{II})$ showed no further decrease in $\mathrm{DPPH}^{\circ}$ concentration after 5 minutes. However, each of the ligands and complex showed low rate of $\mathrm{DPPH}^{\bullet}$ inhibition as compared to Trolox (Fig. 4).
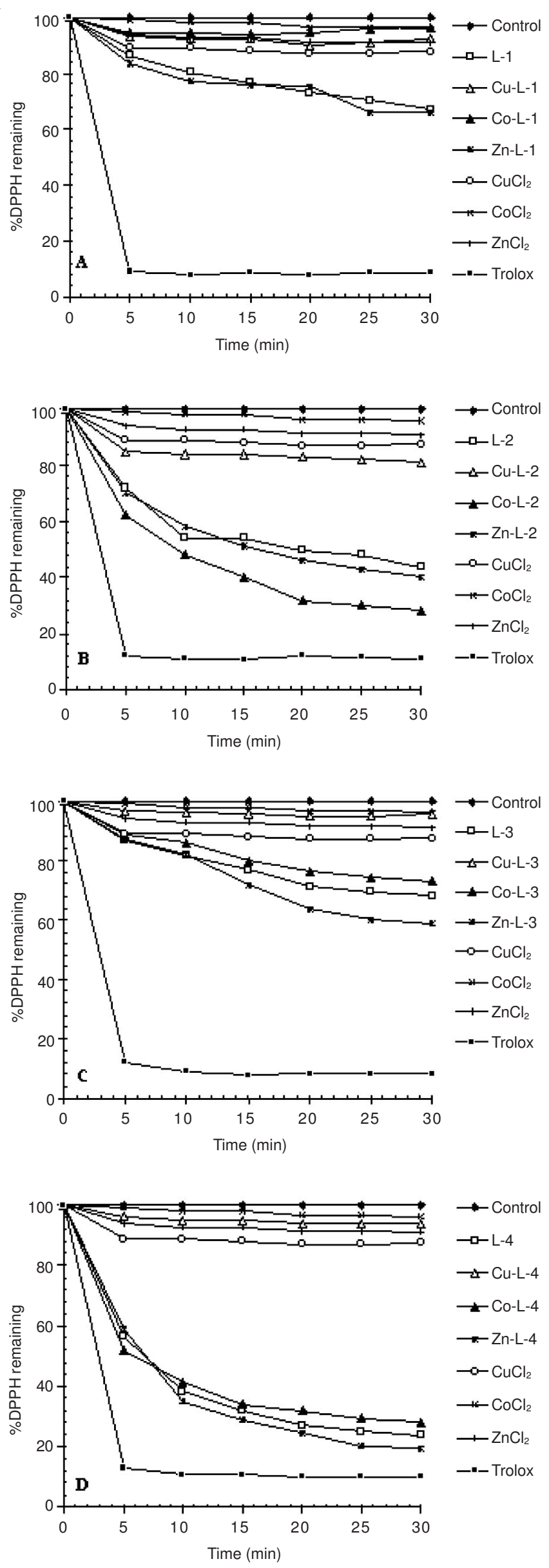


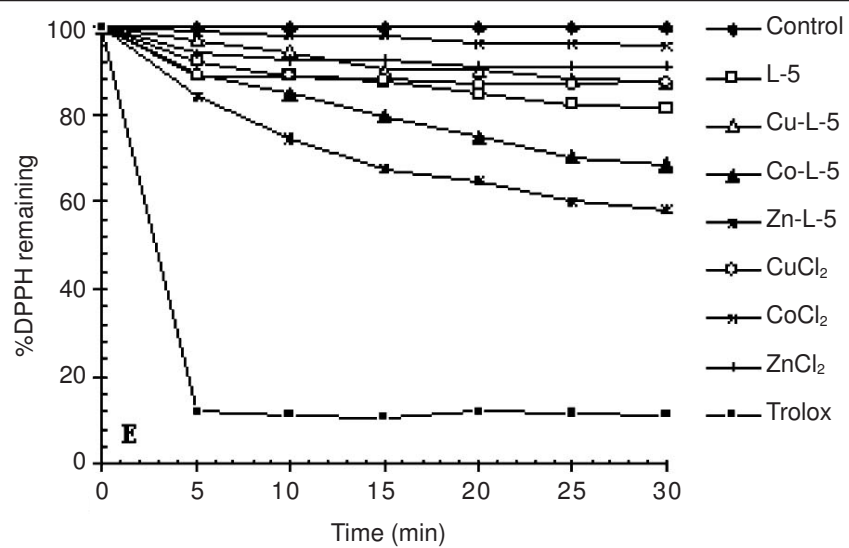

Fig. 4. Kinetic behavior of $\mathrm{DPPH}^{\bullet}$ inhibition by synthesized ligands, their metal complexes, salts of respective metals and a standard antioxidant (Trolox). A: L-1, B: L-2, C: L-3, D: L-4, E: L-5

\section{Conclusion}

All these newly synthesized Schiff's bases were characterized by UV-VIS, IR and ${ }^{1} \mathrm{H}$ NMR spectral data. The mass spectrometric data of these ligands was also in close resemblance with the structures supported by UV-VIS, IR and ${ }^{1} \mathrm{H}$ NMR spectroscopic tools. To determine antioxidant activity of the ligands (L-1, L-2, L-3, L-4 and L-5), their corresponding metal(II) complexes and metal chlorides, Trolox was used as standard antioxidant. Ligand (L-4) was found to be the best antioxidant among all the ligands while among the metal(II) complexes; Zn-L-4 exhibited the best antioxidant activity.

\section{REFERENCES}

1. H. Sies, Am. J. Med., 91, 31S (1991).

2. H. Esterbauer, R.J. Schaur and H. Zollner, Free Radic. Biol. Med., 11, 81 (1991).
3. K. Uchida, Free Radic. Biol. Med., 28, 1685 (2000).

4. G. Leonarduzzi, M.C. Arkan, H. Basaga, E. Chiarpotto, A. Sevanian and G. Poli, Free Radic. Biol. Med., 28, 1370 (2000).

5. R. Stocker, Curr. Opin. Lipidol, 10, 589 (1999).

6. Y.P. Kitaev, B. I. Buzykin and T.V. Troepolskaya, Russ. Chem. Rev., 39, 441 (1970).

7. N.P. Buu-Hoi, N.D. Xuong, N.H. Ham, F. Binon and R. Royer, J. Chem. Soc., 1358 (1953).

8. M. Fabin and G. Palmer, Biochemistry, 40, 1867 (2001).

9. T.S. Ma and T.M. Tian, Antibiot. Chemother, 3, 491(1953); I. Pozdnyakova and P.W. Stafshede, Biochemistry, 40, 13728 (2001).

10. U. Kuehn, S. Warzeska, H. Pritzkow and R. Kraemer, J. Am. Chem. Soc., 123, 6125 (2001).

11. J.M. Price, Fed. Proc., 20, 223 (1961); K.D. Karlin and J. Zubieta, Biochemical and Inorganic Perspectives, Adenine Press Guilderland, New York, p. 457 (1983).

12. A.G. Mauk, R.A. Scott and H.B. Gray, J. Am. Chem. Soc., 102, 4360 (1980).

13. R.J. Williams, J.P. Spencer and C. Rice-Evans, Free Radic. Biol. Med., 36, 838 (2004).

14. F. Virgili and M. Marino, Free Radic. Biol. Med., 45, 1205 (2008).

15. Viswanath, A. Urooj and N.G. Malleshi, Food Chem., 114, 340 (2009).

16. W. Brand-Williams, M.E. Cuvelier and C. Berset, Lebensm. Wiss. Technol., 28, 25 (1995).

17. A.I. Vogel, A Textbook of Quantitative Inorganic Analysis, ELBS and Longman: London, edn. 3, p. 827 (1978).

18. K. Nakamoto, Infrared and Raman Spectra of Inorganic and Coordination Compounds, Wiley Interscience: New York, edn. 3, p. 448 (1978).

19. R.K. Agarwal, J. Indian Chem. Soc., 65, 448 (1988)

20. L.J. Bellamy, Infrared Spectra of Complex Molecules, John Wiley: New York, p. 380 (1975).

21. W.W. Simmons, The Sadler Handbook of Protons NMR Spectra, Sadler Research Laboratories Inc: Philadelphia, p. 80 (1978).

22. D.J. Pasto, Organic Structure Determination, Prentice Hall International: London, p. 451 (1969). 